\title{
Systematic position and variability of the Devonian nautiloids Hercoceras and Ptenoceras from the Prague Basin (Czech Republic)
}

\author{
VOJTĚCH TUREK
}

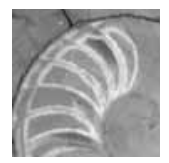

\begin{abstract}
The Devonian nautiloids Hercoceras Barrande, 1865 and Ptenoceras Hyatt, 1894 are closely related and should be classified within the single oncocerid family of Hercoceratidae Hyatt, 1884, which has priority before the family Ptenoceratidae Teichert, 1939. This is supported particularly by the similarity of their embryonic shell and by the character and ontogeny of ventrolateral outgrowths. The intraspecific variability of shells in Hercoceras mirum Barrande, 1865 (Lower Devonian, Prague Basin, Czech Republic) is striking and unusual among nautiloids. The variability in Ptenoceras alatum (Barrande, 1865) is also high, demonstrating fluent transitions between individual morphotypes. Therefore, the other two species of this genus described from the Pragian Stage of the Prague Basin, Ptenoceras modicum (Barrande, 1877) and Ptenoceras barrandei Zhuravleva, 1974 should be assigned to the single species Ptenoceras alatum. $•$ Key words: Cephalopoda, Nautiloidea, taxonomy, variability, Lower Devonian, Prague Basin, Barrandian.
\end{abstract}

TUREK, V. 2007. Systematic position and variability of the Devonian nautiloids Hercoceras and Ptenoceras from the Prague Basin (Czech Republic). Bulletin of Geosciences 82(1), 1-10 (7 figures). Czech Geological Survey, Prague. ISSN 1214-1119. Manuscript received January 8, 2007; accepted in revised form February 13, 2007; issued March 30, 2007. • DOI 10.3140/bull.geosci.2007.01.1

Vojtěch Turek, National Museum, Department of Palaeontology, Václavské náměstí 68, 11579 Praha 1, Czech Republic; vojtech_turek@nm.cz.

The origin of cephalopods of the order Nautilida has been the subject of wide discussion, in which their roots have been searched for within the Tarphycerida and Oncocerida (see Dzik \& Korn 1992, Zhuravleva 1995, Manda 2001). The question of their origin is complicated by the fact that the taxonomical position of some Lower Devonian genera is doubtful, and cephalopod workers classify them within the former or latter order. This particularly concerns the genera Hercoceras Barrande, 1865 and Ptenoceras Hyatt, 1894. These morphologically striking nautiloids with coiled shells and prominent ventrolateral outgrowths in the form of spines, auricles (in Hercoceras), or long wings near the aperture (in Ptenoceras), have been recently discussed by Dzik (1984), Turek \& Marek (1986), Teichert (1988), Dzik \& Korn (1992), Zhuravleva (1995, 2000), and Manda (2001). The type species of both genera exhibit marked variability, well documented in Barrande's illustrations (1865-1877).

In evaluating the variability of the shell in Hercoceras mirum, one exceptionally well-preserved specimen originally from the private collection of V. Plas (NM-L 5946) is important. It shows that the parabolic outgrowths (auricles) that usually develop into spines during ontogeny could persist in the adult stage. The study of additional specimens of Hercoceras mirum and related species, com- bined with careful preparation of the initial whorls of some specimens, has resulted in new data concerning the embryonic shell. The morphological similarity of Hercoceras and Ptenoceras confirms the close relationship of both genera (Korn \& Dzik 1992, Manda 2001), which are classified within the same oncocerid family of Hercoceratidae Hyatt, 1884. It should be noted that Hyatt (1883-1884, p. 283) was the first to postulate a close relationship between Hercoceras mirum and "Gyroceras" alatum. Emphasizing the "similar striae of growth, sutures and ventral siphon" he classified both species within the genus Hercoceras. However, ten years later (Hyatt 1894) selected "Gyroceras" alatum as a type species of the newly established genus Ptenoceras.

The main material studied for the present article (consisting of more than 600 specimens) is deposited in the palaeontological collection of the National Museum in Prague (prefix NM-L before number); additional material (about 20 specimens) used for this study is deposited in the Shary Collection at Harvard University, Massachusetts (prefix MCZ). Specimens were photographed with an Olympus Camedia 5050 digital camera, while more detailed images were made using an Olympus DP 700 digital camera and a JEOL JSM-6380 LV scanning electron microscope. 


\section{Variability and embryonic shell in Hercoceras mirum}

Hercoceras mirum Barrande, 1865 is one of the most common and one of the most unusual Lower Devonian nautiloids of the Prague Basin (Czech Republic). Typical morphologies are characterised by a coiled, depressed, slightly involute shell, with a small umbilical perforation and modified aperture in fully-grown specimens. The suture is almost straight with a shallow ventral lobe. A moderately wide siphonal tube is located near the ventral side. Hercoceras mirum is easily recognizable due to its spine-like, or auricle-like ventrolateral outgrowths (Figs 1, 3).

Hercoceras mirum occurs in red and grey biomicritic limestones representing the upper parts of the Daleje-Třebotov Formation (Dalejan, Upper Emsian, Nowakia richteri and N. holynensis tentaculite zones) (Chlupáč et al. 1979). Almost all specimens come from the surroundings of Prague, such as the Praha-Hlubočepy and Praha-Holyně localities. They were mostly found during the second half of the nineteenth and the first half of the twentieth century. This time span corresponds with the quarrying activities in this area. Most of the larger specimens have been affected by deformation. They are preserved as corroded internal moulds, while the shell, if preserved at all, usually consists only of relics.

Discussion of the variability in Hercoceras mirum necessitates the designation of a lectotype of this highly variable species. In redescribing Hercoceras, Foerste (1926, p. 378) mentioned only the type species and referred to Barrande, p. 152, pl. 43. From this plate he refigured the specimen NM-L 244, illustrated in figs 1-4. This illustration was later adopted in Osnovy paleontologii (Zhuravleva 1962) and the chapter by Kummel et al. (1964) in the Treatise on invertebrate paleontology. However, the specimen should not serve as the lectotype, because Barrande originally assigned it to the above-mentioned species with some doubts: "Hercoceras mirum? varietas irregularis Barr." (see explanation to pl. 43, figs 1-4). Therefore, specimen NM-L 242 illustrated by Barrande (1865) on pl. 42, figs 3, 4, refigured in Zittel (1900, fig. 1071, mirror overturned) is designated here as the lectotype (Fig. 4A-C). This slightly deformed adult specimen with a depressed whorl section and constricted aperture shows originally well developed ventrolateral spine-like outgrowths and partly preserved surface sculpture. It comes from the locality Praha-Hlubočepy, Upper Dalejan (Upper Emsian), Daleje-Třebotov Formation, upper part of the Třebotov Limestone, and is stored together with other paralectotypes in the palaeontological collection of the National Museum in Prague.

The morphological variability exhibited by Hercoceras mirum is considerable, and is unusual among nautiloids:

a) The shell consisting of about three whorls is evolute to slightly involute with a shallow imprint zone, plani- spiral, less frequently slightly torticone, "sinistrally coiled" (the term "sinistrally coiled" is used here in accordance with the article by Teichert in the Treatise on invertebrate paleontology (1964), although the shell of Hercoceras is coiled dextrally relative to the biological orientation of the cephalopod). The adapertural part of the shell in fullygrown specimens sometimes diverges from the inner whorls so that the shell becomes loosely coiled. The size of the shell of mature individuals varies widely attaining 68-130 $\mathrm{mm}$ in diameter. Full-grown specimens are characterised by a modification of the peristome and a constricted aperture. Dorsal and dorsolateral sides of the peristome markedly overlap the ventral side and resemble a visor, which may be bent almost at a right angle and make the apertural opening smaller. Where the last ventrolateral grows out, a hole on each side passing into a slit opened adaperturally may be present (NM-L 395, Barrande 1865, pl. 102, figs 4, 5; NM-L 396, pl. 102, figs 6, 7).

b) The shape of the cross section varies greatly. In the first whorl it is quite uniform, subcircular in cross section, but later becomes subquadratic or subtrapezoidal. It can be strongly depressed, and the extremes on this side of the spectrum show width/height ratios $>2 / 1$. In the latter case, the ventral side is almost flat, while the lateral sides are narrow, passing into steeply inclining umbilical slopes.

c) The size, length and shape of the ventrolateral outgrowths vary markedly. They first appeared on the second whorl, and their shape underwent significant changes during ontogeny. The narrow parabolic outgrowths seen in the earlier whorls develop into hollow, occasionally adaperturally open spines that, in their most adoral development, are markedly stronger and longer than the previous ones, as seen in mature individuals (Fig. 1A-C). The parabolic outgrowths (auricles) sometimes persisted into adulthood (Fig. 3A, B). In such cases the auricles strongly resemble the adapertural wings of Ptenoceras alatum (Barrande, 1865). [The presence of detached, narrow parabolic outgrowths is hardly discernible on corroded internal moulds (Fig. 3C, D).]

d) The variation of the width of the siphuncle (Fig. 2A) is remarkable within this species. However, evaluation of this feature can be biased by the inaccurate illustration of polished sections, which may be slightly offset relative to the median plane.

Barrande (1865) expressed doubts concerning the range of the intraspecific variability in this species. Thus, in addition to Hercoceras mirum, he also described Hercoceras mirum? var. irregularis, which Hyatt (1894) considered as the separate species Hercoceras irregularis. However, a continuous transition exists between both co-occurring morphotypes, and they are herein thought to be variants of a single species. On the basis of this morphotype, Zhuravleva (1974) established the new genus Piratoceras, which is therefore synonymous with Hercoceras. 

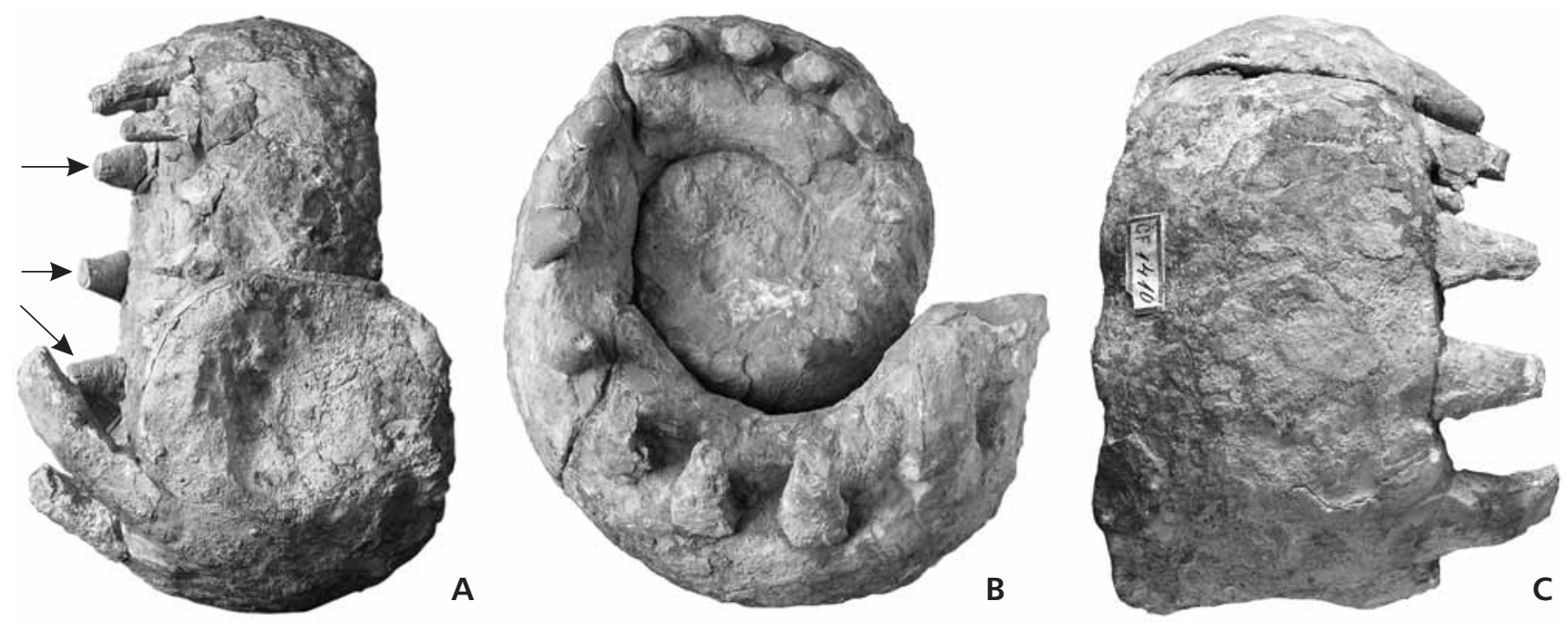

Figure 1. Hercoceras mirum Barrande, 1865. Praha-Hlubočepy, Dalejan, Upper Emsian, Daleje-Třebotov Formation. Typical spiny shell of a fully-grown specimen. Spines indicated by arrows are artificial. Anterior (A), lateral (B) and posterior (C) views. Specimen NM-L 38848 . $\times 0.6$.

The embryonic shell of Hercoceras mirum (Fig. 2B) has a large, cup-like, curved protoconch, with a dorsoventral length of $4.5 \mathrm{~mm}$ and a height of $2.7 \mathrm{~mm}$. The umbilicus is open with a small droplet-shaped umbilical perforation. The first chamber behind the protoconch is about $1.5 \mathrm{~mm}$ high measured along the axis of the shell, and the following two chambers are progressively shortened, whilst the height increases in the fourth and fifth chambers. A nepionic constriction has not been identified in this specimen (MCZ 136857) or in others (e.g., NM-L 38846, Fig. 5A). The cross section of the shell is almost circular in the first whorl, and gradually passes adorally into a subtrapezoidal section. The surface sculpture in what is regarded here as an embryonic shell (NM-L 38846, Fig. 5A, B) bears marked transverse, densely spaced growth lines. Protoconch is smooth what can be demonstrated in specimen NM-L 39014. An observable change in sculpture occurs when the shell reaches about $140^{\circ}$ of the first whorl (measured along the axis of the shell). This change is interpreted as the beginning of the post-hatching phase. Slightly undulating growth lines that are oblique to the axis become more widely spaced here, and shallow ventrolateral sinuses appear at regular intervals at the end of the first whorl. These features indicate the development of narrow, laterally oriented, parabolic outgrowths (auricles), which can persist through ontogeny into the mature growth stages of the shell (NM-L 5946). It seems probable that the last auricles were significantly larger than the previous ones, although it cannot be demonstrated in this specimen. These outgrowths frequently become narrower, and finally resemble spines (see Barrande 1865, Dzik \& Korn 1992). A pair of extremely long spines appears near the aperture of the full-grown specimens. In frontal view they are oriented dorsolaterally. However, the general appearance of specimens preserved only as corroded internal moulds can differ by being almost smooth or by showing only inconspicuous nodes.

The ontogenetic development of the ventrolateral outgrowths, with the presence of a markedly larger pair of adapertural outgrowths in several Lower Devonian nautiloids, are considered to be a significant feature indicating a common ancestor. Outgrowths in Hercoceras thus show an identical origin, and in some cases a shape very similar to the "wings" in Ptenoceras.

Regardless the fact that Hercoceras is one of a number of very common nautiloid taxa, the recovery of a specimen with muscle scars preserved is unlikely due to the mode of preservation in the Třebotov Limestone.

The specimen figured by Barrande (1865, pl. 102, figs 1-3, NM-10084) was supposed to be tightly coiled (comp. Dzik \& Korn 1992). However, though the apical part of the first whorl is not well preserved, the presence of a small umbilical perforation is indicated. The presence of a small umbilical perforation was also confirmed in some of the other specimens mentioned above.

\section{Variability and relationships in Ptenoceras}

Two specimens illustrated by Barrande (1865) on pl. 44, fig. 9 (NM-L 9090) and fig. 10 (NM-9091) were later refigured by Foerste (1926), in Osnovy paleontologii (Zhuravleva 1962), Treatise on invertebrate paleontology (Kummel et al. 1964), and in Teichert (1967, 1988). The latter specimen (NM-9091, Fig. 6A) is hereby designated as the lectotype of Ptenoceras alatum. The adult specimen has a loosely coiled shell, and its ventrolateral wings are broken. It comes from the Koněprusy locality, Pragian, Praha For- 

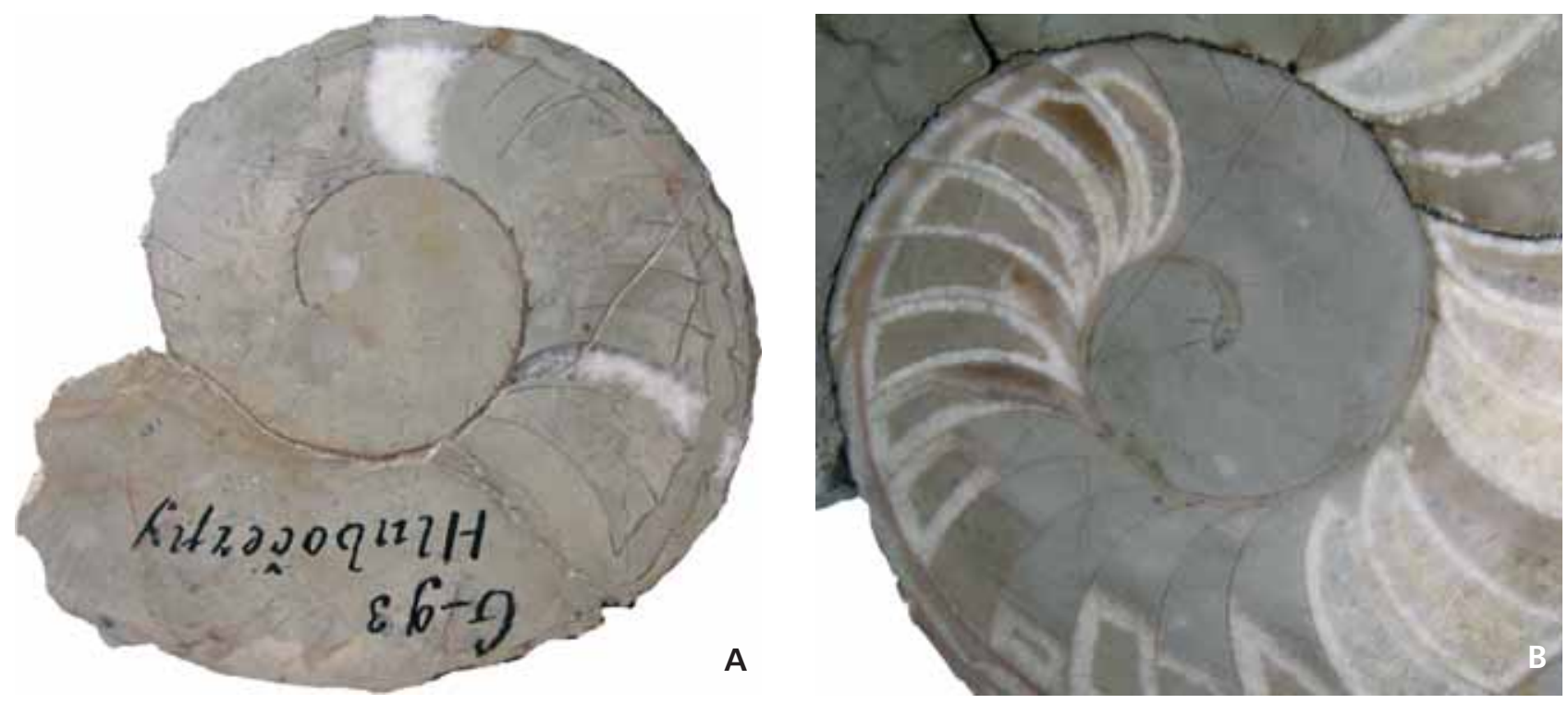

Figure 2. Hercoceras mirum Barrande, 1865. Praha-Hlubočepy, Dalejan, Upper Emsian, Daleje-Třebotov Formation. • A - median polished section showing the siphuncle, specimen MCZ 136633. $\times 1 . \bullet$ B - embryonic shell in a median section. Relics of septa are preserved close to the dorsal side. Specimen MCZ 136857. × 2.7.

mation, Koněprusy Limestone. The specimen is stored in the palaeontological collection of the National Museum in Prague.

The genus Ptenoceras was established by Hyatt (1894). It is characterised by a gyroconic, moderately depressed shell, a narrow siphuncle situated close to the venter, an almost straight suture and ventrolateral wing-like outgrowths, the last pair of which is markedly developed. The type species of this genus, Ptenoceras alatum, is a common and characteristic nautiloid of the Lower Devonian Koněprusy Limestone of the Prague Basin. They were deposited in the environment of the coral-algae reef, and along its periphery. It also occurs less frequently in the micritic Dvorce-Prokop Limestone, deposited in the deeper or transitional facies, i.e. Slivenec and Loděnice limestones (Manda 2001).

Shells of this species consisting of $1 \frac{1}{2}$ whorls do not exceed $60 \mathrm{~mm}$ in diameter. They show great variability in shape and rate of expansion, including the shape of the cross section of the whorl and the development of wings in full-grown specimens. Although the shell in Ptenoceras alatum is generally gyroconic, in some specimens is has a slight "sinistral" coiling. The weakly to moderately depressed elliptical cross section may pass into a roundly polygonal shape with a slight keel. The width/height ratio of the whorl ranges from 1.3-1.5 in adult specimens. Two pairs of wing-like outgrowths usually appear in fullygrown specimens, the last one being more strongly developed. In some specimens, markedly developed outgrowths are present in the middle of the last whorl. Nevertheless, they are usually represented by only distinctly raised growth lines. The growth lines are accentuated ventro- laterally where they form a conspicuous narrow sinus. The embryonic shell of Ptenoceras has a cup-like, curved protoconch and is very similar to the embryonic shell of Hercoceras. It was observed in Ptenoceras alatum, but is better documented in Ptenoceras proximum (Barrande, 1865); see Figs 5C, 6B.

Barrande also assigned a specimen with a slender, more loosely coiled shell to Ptenoceras alatum (pl. 103, figs 17-20), though this was later reassigned by Zhuravleva (1974) to a new species P. barrandei. However, gradual transitions existing between both "species" confirm Barrande's opinion, and Ptenoceras barrandei should therefore be regarded as synonymous with Ptenoceras alatum. This is also in accordance with Dzik (1984, pl. 42, fig. 2a, b), who determined the same morphotype, i.e. Ptenoceras alatum. Ptenoceras modicum (Barrande, 1865) from the Dvorce-Prokop limestones was correctly recognised by Novák (1886) as a synonym of Ptenoceras alatum.

The oldest Ptenoceras (lower Lochkovian) was reported by Zhuravleva (2000) from Novaya Zemlya. Ptenoceras gornense Zhuravleva, 2000, based on a single specimen, closely resembles Ptenoceras alatum of the Pragian Stage. Interestingly, Zhuravleva mentioned the presence of intrasiphonal deposits in this species, the nature of which is unclear (see p. 24). However, they were neither figured nor described, and as such deposits have not been confirmed in any specimen of Ptenoceras alatum or Ptenoceras proximum (Barrande, 1865), their presence in Ptenoceras gornense should be regarded as questionable.

A gyrocone nautiloid described by Novák (1886) as "Gyroceras" kayseri Novák, 1886 comes from the uppermost Lochkovian strata of the Central Bohemia. The 

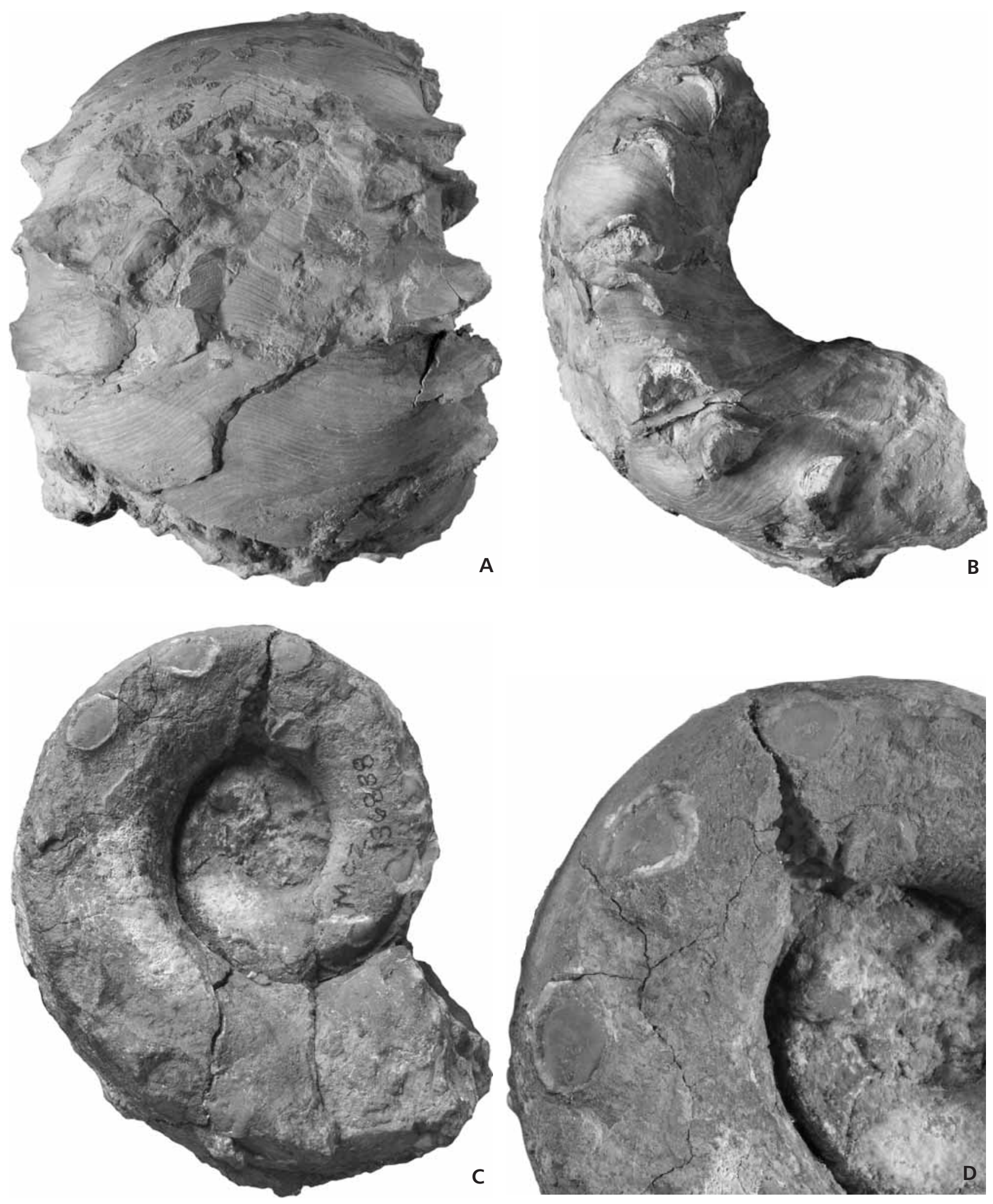

Figure 3. Hercoceras mirum Barrande, 1865; Dalejan, Upper Emsian, Daleje-Třebotov Formation. • A, B - Praha-Holyně, Prastav Quarry. Part of the last whorl with auricle-like ventrolateral outgrowths developed in adult growth stage. Lateral (A) and posterior (B) views. Specimen NM-L 5946. $\times 0.9$. C, D - Praha-Hlubočepy. Internal mould of an immature specimen with its outgrowths broken off. Specimen MCZ 136838. × 1.2. Lateral view (C) and detail showing the mode of growth of shell just after secretion of the outgrowths (D). $\times 2.2$. 

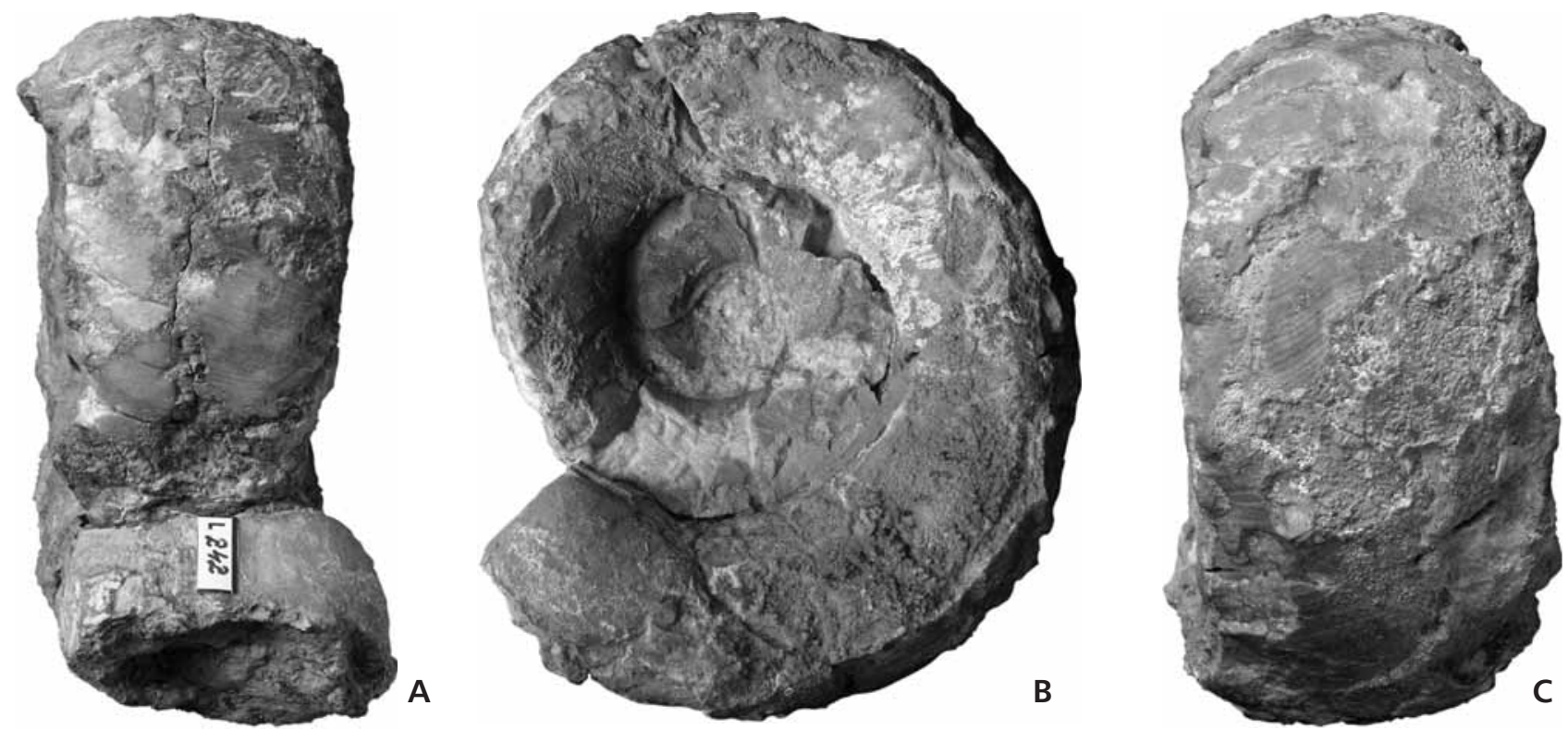

Figure 4. Hercoceras mirum Barrande, 1865. Praha-Hlubočepy, Dalejan, Daleje-Třebotov Formation. The lectotype NM-L 242, illustrated by Barrande (1865), pl. 42, figs 3, 4. Adult specimen with typical constriction of the aperture. Anterior (A), lateral (B) and posterior (C) views. NM-L 38848. $\times 0.7$.

holotype of this species (NM-L 9089) has an incomplete last whorl, partly exfoliated, with the body chamber preserved as an internal mould. Growth lines that are accentuated in regular intervals are traceable on the surface. They show wide and shallow lateral lobes but narrower and deeper ventral lobes, i.e. their course is similar to that of Ptenoceras alatum. However, there are no traces indicating the presence of a pair of wing-like outgrowths behind the aperture - the feature characteristic of the type species of the genus Ptenoceras. Manda (2001) tentatively assigned "Gyroceras" kayseri to the genus Trochoceras.

The history of Ptenoceras during the Zlichovian Age is not well known. Chlupáč (1990) mentioned this genus from the lower parts of the Zlíchov Formation. This rare and fragmentary material, which was donated to the collection of the National Museum in Prague (NM-L 39061-2, NM-L 39214) is strongly affected by deformation. It apparently belongs to the related oncocerid genus Goldringia Flower, 1945, though reported from the Pragian Stage (Praha Formation) of the Prague Basin (comp. Manda 2001). It is assigned to the species Goldringia gondola Manda, 2001. The stratigrafically youngest species of Ptenoceras from the Prague Basin is Ptenoceras proximum (Barrande, 1865) (see Chlupáč 1976). It comes from the Daleje-Třebotov Formation (Třebotov and Suchomasty limestones, Upper Dalejan, i.e. Upper Emsian). Compared to Ptenoceras alatum, the shell of this species is more tightly coiled, finely crenulate ventrolaterally with only one pair of wings near the aperture. Ptenoceras proximum markedly resembles the Middle Devonian (Eifelian) genus Nassauoceras Miller, 1932 and may be its ancestor. The embryonic shell observed in several specimens of Ptenoceras proximum is similar as in Ptenoceras alatum and Hercoceras mirum. The protoconch is cup-like and curved, the umbilical perforation is small and drop-shaped but larger than in H. mirum. Another species of Ptenoceras that more closely resembles the morphology of Ptenoceras alatum than Ptenoceras proximum comes from the same stratigraphic level. It is tentatively classified herein as "Gyroceras" nudum Barrande, 1865. If compared with Ptenoceras alatum, the growth lines in this species are almost uniformly developed and only one pair of wing-like ventrolateral outgrowths is present.

\section{Remarks on the systematics}

The genus Hercoceras was consistently classified within the order Nautilida, family Rutoceratidae Hyatt, 1884 in the Osnovy (Zhuravleva 1962) and the Treatise (Kummel et al. 1964). According to the concept of Dzik (1984), the Rutoceratidae could belong to the Oncocerida, though that author included Hercoceras in the family Trochoceratidae Zittel, 1884 of the Nautilida. Later Dzik \& Korn (1992) emphasised the close similarity between Ptenoceras and Hercoceras, considering them as possible nautilids. Zhuravleva (1995) assigned Hercoceras to the family Rutoceratidae (order Nautilida). In describing Parakophinoceras arcticum Zhuravleva, 1995 from the Lower Devonian of Novaya Zemlya, she emphasized the similarity of the initial parts of this species and Hercoceras (as illustrated by Hyatt 1894), noting that in both cephalopods "the initial chamber is much longer than the next two chambers, but 
after an even shorter third chamber, the chamber lengths again gradually increase" (Zhuravleva 1995, p. 21). This corresponds to the length (= height) of chambers observed in specimen MCZ 136857 described herein. According to Zhuravleva, Hercoceras most closely resembles Phaseloceras Zhuravleva, 1995. However, the latter genus differs in that the siphonal necks form a fold that faces toward the aperture on the dorsal side, whilst the nodes are situated in a more ventral position. In discussing other Lower Devonian cephalopods, Manda (2001) concurred with Dzik's opinion concerning the position of the Rutoceratidae within the Oncocerida, where Manda also placed the family Trochoceratidae Zittel, 1884.

The systematic position of Ptenoceras has been widely discussed and is the subject of controversy with regard to its ordinal position (comp. Zhuravleva 1962, Kummel et al. 1964). The illustration of deposits within the siphuncle (Barrande 1865 , pl. 44, figs 15,16 ) was misguiding, and their presence in the type species has not been confirmed (Dzik 1984, Turek in Teichert 1988). Discovery of the oncocerid type of muscle scars in Ptenoceras (Turek \& Marek 1986) supports the opinion of Zhuravleva (Zhuravleva 1962, 1974, 2000) that this genus should be placed amongst the oncocerids (see also Teichert 1988, Manda 2001).

Although the Nautilida exhibit a wide variety of coiling, whorl cross-sections and ornamentation, there are no deviations from the planispiral model (Teichert 1988). However, such coiling did occur in some populations of Ptenoceras and Hercoceras. The form and sculpture of the embryonic shell in both genera show a great similarity with these features in other oncocerids, but differs markedly from the horn-like shape of embryonic shells of the Upper Palaeozoic nautilids (comp. Shimanskij 1967). The nepionic constriction of shell, which is characteristic of postTriassic Nautilida as well as for the recent Nautilus (Chirat 2001), has not been observed in the cephalopods discussed here.

\section{Ecological notes}

The broad, evolute or slightly involute shell of Hercoceras mirum and the gyrocone shell of Ptenoceras alatum, in some cases coiled in both genera into a low trochoceroid spire and a wide umbilicus, could disable any rapid movement by the living animal. The laterally protruding, thick walled outgrowths that appear early during the ontogeny in Hercoceras, combined with the shell that passes into an uncoiled portion adaperturally, and the character of apertural modification, is here regarded as a further disadvantage for active swimming. The aperture of fully-grown specimens was thus oriented obliquely downward. The relation of Hercoceras mirum to the sea floor indicates that a benthic mode of life may be inferred for this cephalopod.
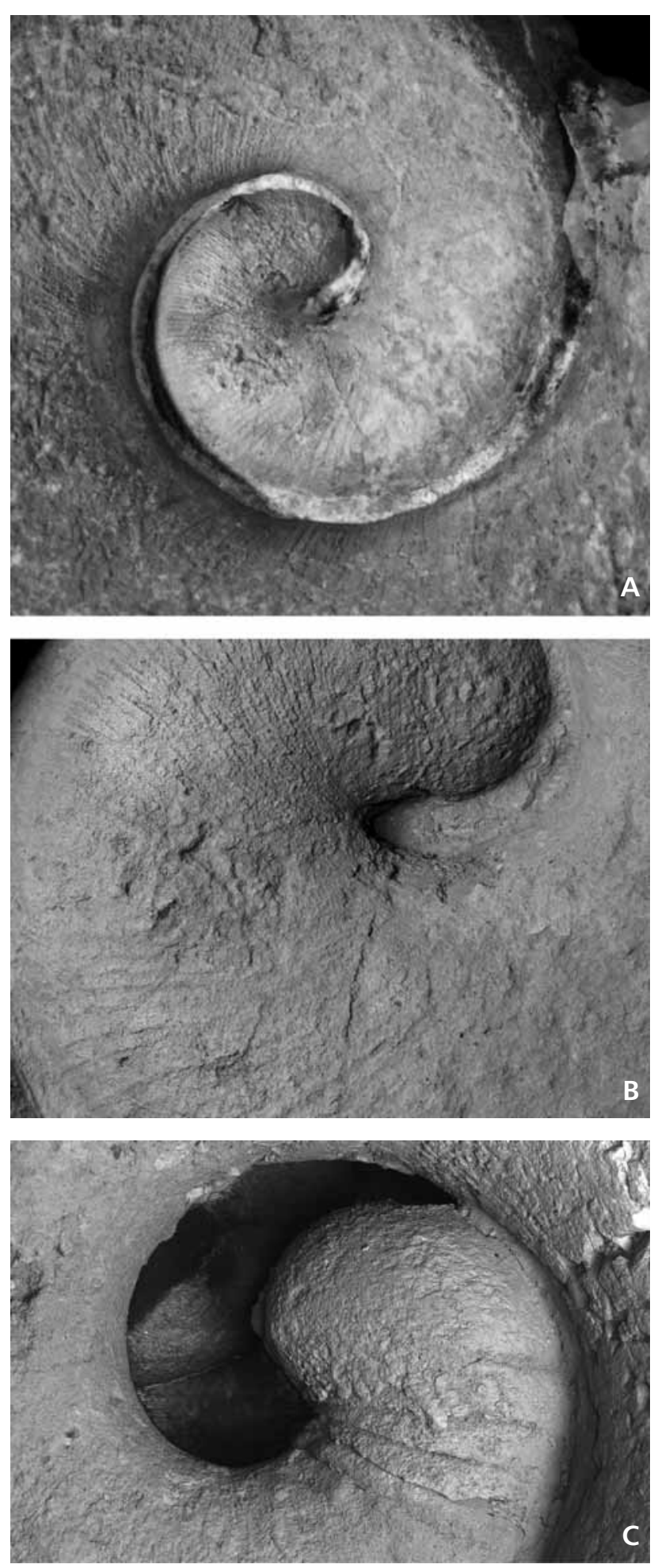

Figure 5. A, B - Hercoceras mirum Barrande, 1865. Praha-Hlubočepy. Dalejan, Upper Emsian, Daleje-Třebotov Formation. • A - First whorl with preserved sculpture on the embryonic shell. Coated with ammonium chloride before photographing. $\times 3.6$. Specimen NM-L 38846. $\bullet B-$ detail of shell surface in SEM showing change in density of growth lines indicating the post hatching stage $\times 9$. $・ \mathrm{C}-$ Ptenoceras proximum (Barrande, 1865). Praha-Hlubočepy. Dalejan, Upper Emsian, Daleje-Třebotov Formation. Detail of embryonic shell; internal mould (see fig. $6 \mathrm{~B}$ ). $\times 7.8$. 

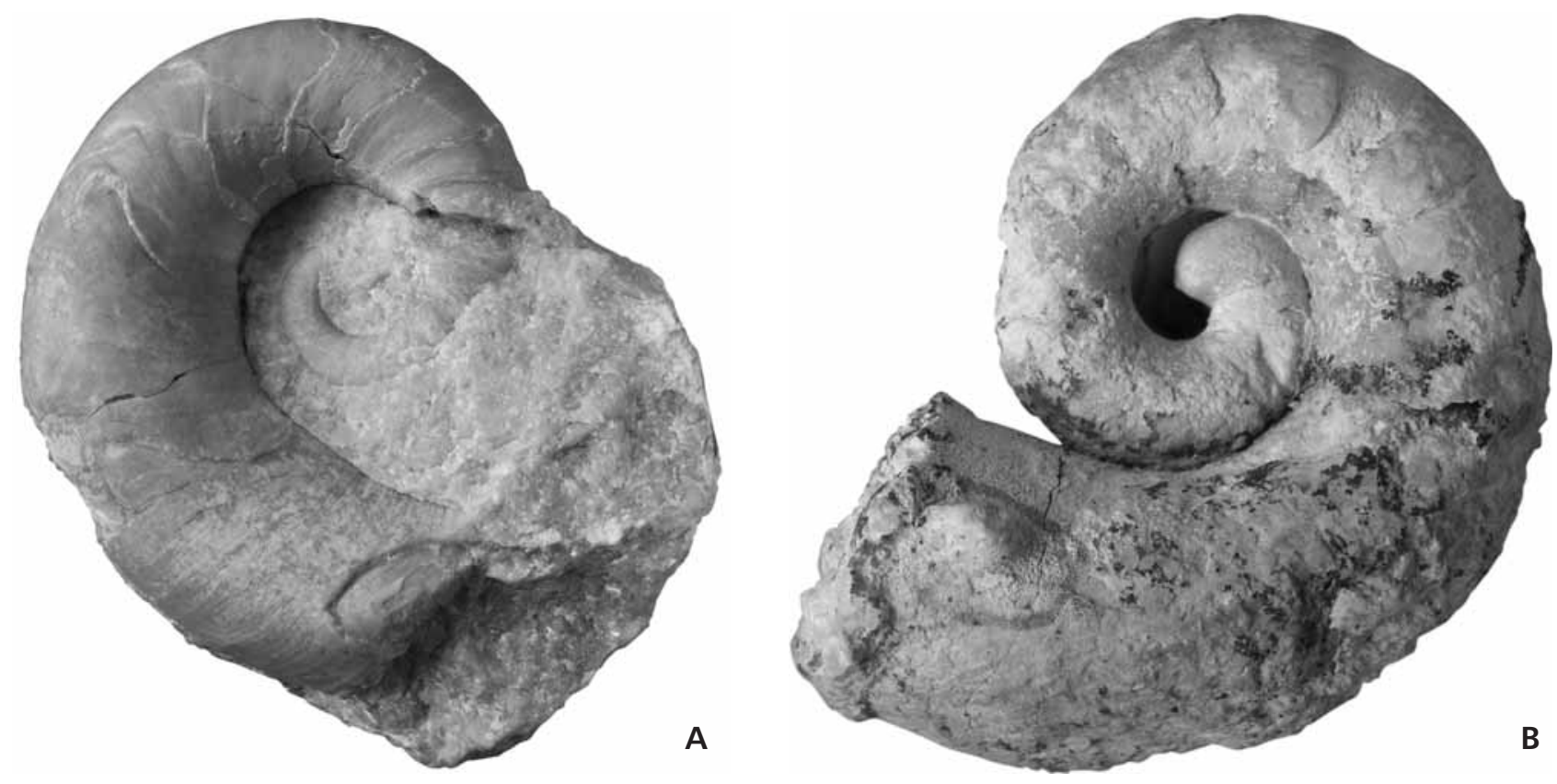

Figure 6. A - Ptenoceras alatum (Barrande, 1865). Koněprusy, Pragian, Praha Formation, Koněprusy Limestone. Lateral view. The lectotype NM-L 9091, illustrated by Barrande (1865), pl. 44, fig. 10. × 1.3. • B - Ptenoceras proximum (Barrande, 1865). Praha-Hlubočepy, Dalejan, Upper Emsian, Daleje-Třebotov Formation. Lateral view. Specimen NM-L 38849. $\times 2.8$.

The shell of Ptenoceras alatum had better hydrodynamic properties. The surface was usually almost smooth in younger growth stages, with only periodically raised and more undulatory growth lines. One or two pairs of wing-like outgrowths appear in maturity. The adapertural wings are much longer than the wings of the previous pair, and might have improved the stability of the shell in high-energy environments and provided the animal with better mechanical protection in the reef environment. The increase in the adult size of the animal might also have provided protection against predators. Ptenoceras alatum was especially common in reef and forereef environments. It also inhabited deeper water, as can be inferred from its occurrence in other facies, including those of the micritic limestone. The known geographic distribution of Ptenoceras alatum is much wider than Hercoceras mirum, which may support the opinion that Ptenoceras alatum was a better swimmer than Hercoceras mirum.

The development of spine-like outgrowths or auricles demonstrates the periodic lateral spreading of the mantle margin, which was extreme in full-grown specimens. The functional significance of these structures is questionable. For Ptenoceras, they may have provided a protective function in the event of collisions in the high-energy reef environment. Conversely, Hercoceras (Fig. 7) inhabited deeper and quieter water close to the bottom, and so a protective role for spines seems more probable. The appearance of outgrowths in even earlier ontogenetic stages supports this opinion. The possibility that the development of out- growths is a metabolic response to overproduction of calcium carbonate is also considered.

\section{Conclusions}

A very high intraspecific variability of shells in the Lower Devonian nautiloids Ptenoceras alatum (Barrande, 1865) and particularly in Hercoceras mirum Barrande, 1865 (Prague Basin, Czech Republic) is unusual among coiled nautiloids. It indicates that neither the shell form nor sculpture was under strong selection pressure. Fluent transitions between individual morphotypes confirm that a questionable subspecies described as Hercoceras mirum? var. irregularis Barrande, 1865 (Upper Dalejan) fits into the range of variation observed in Hercoceras mirum. The genus Piratoceras Zhuravleva, 1974 established on the basis of this morphotype is therefore synonymous with Hercoceras. All the described Ptenoceras species of Pragian age - Ptenoceras alatum (Barrande, 1865), P. modicum (Barrande, 1877) and Ptenoceras barrandei Zhuravleva, 1972 - represent a single species.

Specimens of Ptenoceras alatum with "juvenile" wing-like outgrowths appearing in immature growth stages, and adult shells of Hercoceras mirum bearing auricle-like ventrolateral outgrowths, represent marginal morphotypes within populations of these cephalopods. The characteristics of these individuals support the hypothesis that Hercoceras is derived from Ptenoceras, 
and should be classified within the same family of the Oncocerida.

Hyatt (1883) established the family Hercoceratidae, in which he included Hercoceras mirum and Hercoceras alatum, the latter subsequently established as a separate genus Ptenoceras (Hyatt 1894). As demonstrated here, the position of both genera in the same family is well founded, and therefore the family Ptenoceratidae Teichert, 1939 is regarded here as a younger synonym of Hercoceratidae. It includes nautiloids with gyrocone to slightly involute, exogastric, planispiral or slightly torticone shells. The narrow to moderately wide siphuncle with fusiform segments is empty, and is situated near the ventral side. The sculpture is characterised by ventrolateral outgrowths in the form of spines, auricles or wings appearing in different ontogenetic stages. At least one pair of these outgrowths is situated near the aperture. Muscle scars are of the oncocerid type. The following genera are classified here within the Hercoceratidae family: Hercoceras Barrande, 1865, Ptenoceras Hyatt, 1894 (including Doleroceras Zhuravleva, 1972), and Ptyssoceras Hyatt, 1884. Hercoceratidae show parallel evolution with lineages represented by the families Trochoceratidae Zittel, 1884 and Rutoceratidae Hyatt, 1884 during the Pragian (see Manda 2001).

Unfortunately, the history of the genera Hercoceras and Ptenoceras during the Zlichovian and lower Dalejan ages remains inadequately known. The few poorly preserved specimens from Lower Zlichovian strata, formerly assigned to Ptenoceras, belong to the genus Goldringia, so far reported only from the Pragian Stage of the Bohemian Palaeozoic. The evolution of the genus Ptenoceras can be followed through the entire Lower Devonian (Lower Lochkovian to Upper Dalejan). The oldest known representative Ptenoceras gorgense Zhuravleva, 2000, the Pragian Ptenoceras alatum (Barrande, 1865), and the youngest Ptenoceras resimum (Zhuravleva, 1972) reported from the Eifelian of the east slope of the Central Ural Mts., are morphologically very similar. The ventrolateral wings, most developed in the Pragian species Ptenoceras alatum, were later reduced to one pair appearing near the aperture of the adult specimens, and the size of the wings decreased. Such a tendency is well expressed in the Dalejan species Ptenoceras proximum (Barrande, 1865) (Chlupáč 1976).

In the derived lineage comprising Hercoceras, the evolutionary trend resulted in large aberrant forms, with a more tightly coiled shell having a smaller umbilical perforation, a divergent body-chamber and a modified aperture. Parabolic ventrolateral outgrowths, which appeared earlier in the ontogeny, show a tendency to transform into hollow adaperturally opened spines.

Ptenoceras alatum is regarded a having a nectobenthic mode of life, whilst the poor hydrodynamic properties of the shell of $H$. mirum is interpreted here to indicate a benthic habit with a limited ability for active swimming.

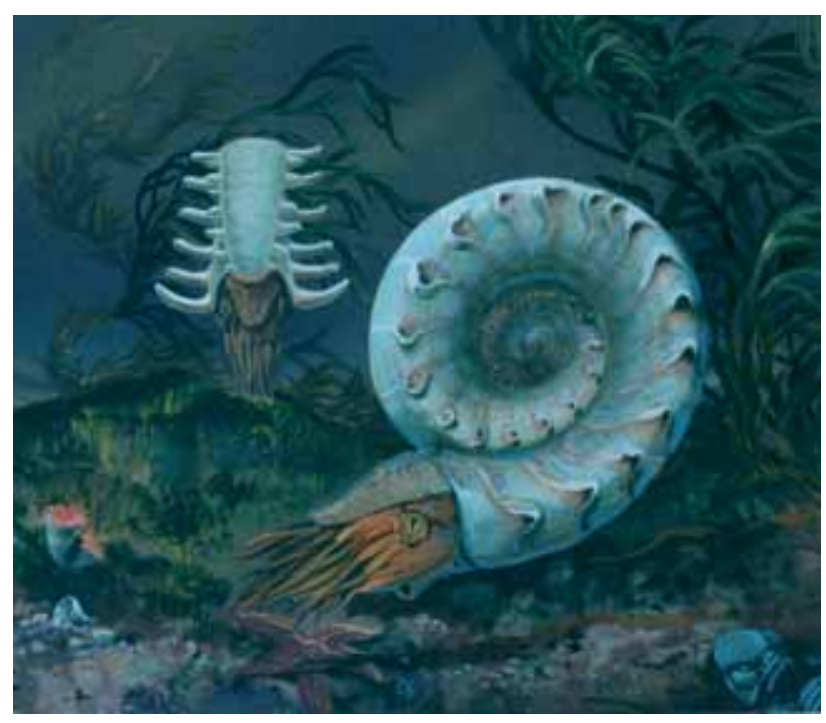

Figure 7. Hercoceras mirum Barrande. Spiny and auriculate but not yet fully-grown specimens. Reconstruction J. Sovák.

\section{Acknowledgements}

This research was supported by the Czech Grant Agency through the project GAČR 2005/05/0875. The author thanks Fred Collier and Jessica Cundiff (Museum of Comparative Zoology, Harvard) for providing the material used in this study, Radvan Horný (National Museum, Prague) and two reviewers, David H. Evans (Natural England, Peterborough) and Štěpán Manda (Czech Geological Survey, Prague) for their critical reading of the manuscript, Martin Mazuch (Charles University, Faculty of Natural Sciences, Prague) for SEM photographs and Jan Sklenář (National Museum, Prague) for technical help.

\section{References}

BARRANDE, J. 1865-1877. Systême silurien du centre de la Bohême. Recherches paléontologiques, İre partie, vol. II, Céphalopodes. Paris, Praha.

ChIRAT, R. 2001. Anomalie of embryonic shell growth in postTriassic Nautilida. Paleobiology 27(3), 485-499.

DZIK, J. 1984. Phylogeny of the Nautiloidea. Palaeontologia Polonica 45, 1-219.

DZIK, J. \& KoRn, D. 1992. Devonian ancestors of Nautilus. Paläontologische Zeitschrift 66(1/2), 81-98.

FloweR, R.H. 1945. Classification of Devonian nautiloids. American Midland Naturalist 33(3), 675-724.

Foerste, A.F. 1926. Actinosiphonate, trochoceroid and other cephalopods. Denison University Bulletin, Journal of the scientific laboratories 21, 285-383.

Hyatт, A. 1883-1884. Genera of fossil cephalopods. Boston Society Natural History Proceedings 22, 273-338.

HyatT, A. 1894. Phylogeny of an acquired characteristic. American Philosophical Society Proceeding 32, 349-647.

CHLuPÁČ, I. 1976. The Bohemian Lower Devonian stages and re- 
marks on the Lower-Middle Devonian boundary. Newsletter on Stratigraphy 5(2/3), 168-189.

CHLUPÁČ, I. 1990. Structure and environment of the ichnofossil Zoophycos in the Lower Devonian of Bohemia, Czechoslovakia. Časopis pro mineralogii a geologii 35(4), 373-389.

Chlupéč, I., Lukeš, P. \& Zikmundová, J. 1979. The Lower/Middle Devonian boundary beds in the Barrandian area, Czechoslovakia. Geologica et Palaeontologica 13, 125-156.

Kummel, B., Furnish, W.M. \& Glenister, B. 1964. Nautiloidea-Nautilida, 383-457. In Moore, R.C. (ed.) Treatise on invertebrate paleontology, part K, Mollusca 3 . The University of Kansas Press, Lawrence.

MANDA, Š. 2001. Some new or little known cephalopods from the Lower Devonian Pragian carbonate shelf (Prague Basin, Bohemia) with remarks on Lochkovian and Pragian cephalopod evolution. Journal of the Czech Geological Society 46(3-4), 269-285.

Miller, A.K. 1932. The mixochoanites cephalopods. State University Iowa Studies Natural History, new series 14(4), 1-67.

NovÁK, O. 1886. Zur Kenntniss se Fauna dert Etage F-f1 in der Palaeozoischen Schichtengruppe Böhmens. Sitzungsberichte der Keiserlichen Böhmischen Gesellschaft der Wissenschaften 1886, 1-27.

ShimanskiJ, V.N. 1967. Kamenougolnye Nautilida. Trudy paleontologičeskogo instituta 115, 1-257.

TEICHERT, C. 1964. Morphology of the hard parts, 13-59. In MoORE, R.C. (ed.) Treatise on invertebrate paleontology, part K, Mollusca 3. The University of Kansas Press, Lawrence.
TeICHERT, C. 1967. Major features of cephalopods evolution, 162-210. In TeICHERT, C. \& Yochelson, E.L. (eds) Essays in paleontology and stratigraphy. The University of Kansas Press, Lawrence.

Teichert, C. 1988. Main features of cephalopod evolution, 11-79. In Clarke, M.R. \& Trueman, E.R. (eds) The Mollusca, vol. 12: Paleontology and neontology of cephalopods. Academic Press, Inc., San Diego.

TureK, V. \& MAREK, J. 1986. Notes on the phylogeny of the Nautiloidea. Paläontologische Zeitschrift 60(3-4), 245-253.

Zhuravleva, F.A. 1962. Otrjad Oncocerida, 101-104. In RuZHENCEV, V.E. (ed.) Osnovy paleontologii. Molljuski Golovonogie. I. Izdatelstvo Akademii nauk SSSR, Moskva.

ZHURAVlEVA, F.A. 1972. Otpechatki muskulov-retraktorov u devonskich ptenoceratid. Paleontologičeskij žurnal 1972(1), 134-136.

Zhuravleva, F.A. 1974. Devonskie nautiloidei. Otrjady Oncocerida, Tarphycerida and Nautilida. Trudy paleontologičeskogo instituta 142, 1-160.

Zhuravleva, F.A. 1995. New early Devonian nautilids from Novaya Zemlya and Taimyr. Paleontological Journal 29(4), 20-35.

ZhURAVleVA, F.A. 2000. Novye ranedevonskie onkoceridy (Cephalopoda) Novoj Zemli. Paleontologičeskij žurnal 6, 18-25.

ZitTel, K.A. 1884-1885. Handbuch der Palaeontologie, Abt. 1, Bd. 2, Mollusca und Arthropoda. 893 pp. München, Leipzig.

ZitTEL, K.A. 1900. Text-book of Palaeontology. 706 pp. Macmillan and Co., New York. 